\title{
Erratum to study on the mechanism of the Modified Ginseng-Schisandra Decoction (MGSD) in the treatment of recurrent respiratory tract infection (RRTI) based on network pharmacology
}

\author{
Editorial Office \\ Translational Pediatrics \\ Correspondence to: Editorial Office. Translational Pediatrics. Email: editor@thetp.org. \\ Submitted Aug 13, 2020. Accepted for publication Aug 17, 2021. \\ doi: $10.21037 /$ tp-21-416 \\ View this article at: https://dx.doi.org/10.21037/tp-21-416
}

Erratum to: Transl Pediatr 2021;10:1701-11

The article entitled "Study on the mechanism of the Modified Ginseng-Schisandra Decoction (MGSD) in the treatment of recurrent respiratory tract infection (RRTI) based on network pharmacology" (1) that appeared on Page: 1701-1711, Vol 10, No. 6 (June 2021) unfortunately contained a mistake in the section of Funding. The corrected information is presented as below.

Funding: Shanghai Municipality's three-year action plan for further accelerating the development of Chinese medicine (20182020) [ZY (2018-2020)-FWTX-4023, ZYPY (2018-2020)-043]; Shanghai Municipal Health Commission's Maternal and Child Health TCM Special Construction Project (FYJKZY-EB-2).

Click here to view the updated version of the article.

Open Access Statement: This is an Open Access article distributed in accordance with the Creative Commons AttributionNonCommercial-NoDerivs 4.0 International License (CC BY-NC-ND 4.0), which permits the non-commercial replication and distribution of the article with the strict proviso that no changes or edits are made and the original work is properly cited (including links to both the formal publication through the relevant DOI and the license). See: https:// creativecommons.org/licenses/by-nc-nd/4.0/.

\section{References}

1. Cui QK, Li H, Li Z, et al. Study on the mechanism of the Modified Ginseng-Schisandra Decoction (MGSD) in the treatment of recurrent respiratory tract infection (RRTI) based on network pharmacology. Transl Pediatr 2021;10:1701-11.

Cite this article as: Editorial Office. Erratum to study on the mechanism of the Modified Ginseng-Schisandra Decoction (MGSD) in the treatment of recurrent respiratory tract infection (RRTI) based on network pharmacology. Transl Pediatr 2021;10(9):2408. doi: 10.21037/tp-21-416 